\title{
CAPITAL AND PROFIT-TAKING PERCENTAGE INFLUENCE REVENUE OF GROCERY STORES IN KARANG ANYAR, LANGSA
}

\author{
${ }^{1}$ Aisyah Vania \\ *Talbani Farlian \\ ${ }^{1}$ Student of Accounting Department, Faculty of Economics and Business, Syiah Kuala \\ University, Indonesia \\ Email: aisyahvania13@gmail.com
}

*Corresponding Author: $\underline{t \text { farlian@unsyiah.ac.id }}$

\begin{abstract}
This study aims to analyze capital and profit-taking percentage influance on the revenue of grocery stores in Karang Anyar, Langsa. This study uses primary data and the method used to collect primary data is field research methods. The sample selection used Slovin sampling technique. By using Slovin formula, a population of 5 grocery stores and an error limit of 5 percent, obtained a sample of 5 grocery stores. The data analysis technique used to solve problem in the study is multiple linear regression analysis techniques. Based on calculation of Eviews 11, the simultaneous test results show that capital and percentage of profit-taking percentage have a significant effect on the revenue of grocery stores in Karang Anyar, Langsa. Capital and percentage of profit taking partially have a positive and significant effect on the revenue of grocery stores in Karang Anyar, Langsa
\end{abstract}

Keywords: Capital, profit-taking percentage, revenue.

Penelitian ini bertujuan untuk menganalisis modal dan persentase pengambilan keuntungan terhadap pendapatan toko-toko kelontong di Karang Anyar, Langsa. Penelitian ini menggunakan data primer dan metode yang digunakan untuk mengumpulkan data primer adalah metode penelitian lapangan. Pemilihan sampel menggunakan teknik Slovin sampling. Dengan menggunakan rumus Slovin, dari populasi 5 toko kelontong dan batas kesalahan 5 persen, diperoleh sampel 5 toko kelontong. Teknik analisis data yang digunakan untuk menyelesaikan masalah dalam penelitian adalah teknik analisis regresi linier berganda. Berdasarkan perhitungan Eviews 11, hasil pengujian secara simultan menunjukkan bahwa modal dan persentase pengambilan keuntungan berpengaruh signifikan terhadap pendapatan toko-toko kelontong di Karang Anyar, Langsa. Modal dan persentase pengambilan keuntungan secara parsial berpengaruh positif dan signifikan terhadap pendapatan toko-toko kelontong di Karang Anyar, Langsa.

Kata kunci: Modal, persentase pengambilan keuntungan, pendapatan 


\section{INTRODUCTION}

Karang Anyar has various kinds of businesses. Starting from the grocery stores, clothes shop, food shops, vegetable shops, chip shops, mobile vendors and others. This effort has been done by the people of Karang Anyar for a long time. The oldest business was a grocery store. One of the grocery stores in Karang Anyar has opened its shop for 35 years. This shows that Karang Anyar is a developed village. However, currently the grocery stores in Karang Anyar is growing rapidly and getting bigger. There are 5 grocery stores in Karang Anyar. Many buyers come from outside the area to shop. They even come from the D4 area which is quite far from Karang Anyar. Not only that, the goods sold in Karang Anyar Grocery stores are many and varied, so buyers can freely choose the items they want to buy. Grocery stores in Karang Anyar are not much different from grocery stores in city area. Even though they are located in the village, the Grocery stores in Karang Anyar are of the same quality as the Grocery stores in the city area.

Grocery stores in Karang Anyar sell a variety of goods. Among them are soap products, cooking oil, sugar, rice, gas, and many other items. Grocery stores owners collect goods directly from agents. Then many food stall owners in Karang Anyar buy necessities for their business at grocery stores. They have long subscribed and trust each other. Not only food shop owners, many people of Karang Anyar also subscribe to grocery stores. In fact, they prefer shopping at grocery stores rather than shopping at the Langsa City market. This is because the price is not too high and the grocery stores owner is friendly.

In starting a business, one of the most important things needed is capital. Capital is an important supporting factor for grocery store owners for the sustainability of their business. Various studies on the informal sector or the development of micro-enterprises always prioritize the role of capital as the main difficulty faced by these business actors. It is possible that this will also affect the level of revenue of grocery store owners. Capital has a positive and significant effect on revenue, this means that the greater the capital expenditure in trading, the greater the revenue earned by grocery store owners. Lack of working capital for some grocery store owners will severely limit the ability to hold an adequate supply of goods.

In selling goods, every grocery stores owner must take advantage. Profit-taking is done to increase the volume of merchandise and invest in valuables with the aim of prospering the grocery stores owner. However, taking profits should not be arbitrary. In addition to burdening buyers, grocery stores owners will feel the impact such as a shortage of buyers due to goods being sold at too high a price. The profit-taking percentage should not be too high, but it should not also hurt the grocery stores owner. Buyers also certainly expect the price of goods to be cheaper, so wholesale shop owners usually don't take much profit. The grocery stores owners have the principle that even though they take a little profit on each item, the sales of the goods are smooth. So that grocery stores owners still get revenue. Then the profit-taking percentage has an effect on the revenue of grocery stores owners.

\begin{tabular}{|c|c|c|c|}
\hline Store & $\mathrm{X} 1$ & $\mathrm{X} 2$ & Y \\
\hline Reza Store & Rp 120.000.000 & $25 \%$ & Rp 138.000.000 \\
\hline Slamet Store & Rp 100.000.000 & $25 \%$ & Rp 110.000.000 \\
\hline Sidik Minyak Store & Rp 20.000 .000 & $35 \%$ & Rp 30.000 .000 \\
\hline Lia Store & $\mathrm{Rp} \quad 14.000 .000$ & $36 \%$ & Rp 20.000.000 \\
\hline Tiga Saudara Store & $\mathrm{Rp} \quad 21.000 .000$ & $38 \%$ & Rp 35.000 .000 \\
\hline
\end{tabular}

Table 1. List of total capital, percentage of profit taking and revenue of grocery stores in Karang Anyar, Langsa 
Information:

X1 = Capital per month

$\mathrm{X} 2$ = Profit-Taking Percentage per month

$\mathrm{Y}=$ Revenue per month

\section{LITERATURE REVIEW}

\section{Definition of Revenue}

Revenue is the amount of money received by a company from an activity it performs, and most of these activities are the activity of selling products and / or selling services to consumers. The word revenue in the business world is not a strange thing. Any business that is involved in the main objective is to generate revenue. Both large and small income businesses can support optimal financial performance.

According to Kieso, Warfield and Weygantd (2011) "revenue is the gross inflow of economic benefits arising from the normal activities of the entity during a period, if the inflow results in an increase in equity that does not come from investment contributions". Then Skousen and Stice (2010) say that "revenue is an inflow or settlement (or a combination of both) of the delivery or production of goods, providing services or carrying out other activities which are the main activity or ongoing central activity."

\section{Definition of Capital}

Every trading, service or industrial company has funds and requires capital, therefore the problem of capital is closely related to day-to-day operations. With good capital management in one period, the capital can be used again in the next period. Martono (2005: 72) states that "capital is a fund that is used to finance a company's day-to-day operations". Capital also refers to all current assets owned by a company or after current assets are reduced by current debt. Or in other words, capital is an investment that is invested in current assets or short-term assets. Usually capital is used for several activities in one period."

Based on the opinions of the experts above, it can be concluded that capital is a fund that is used to finance the company's day-to-day operations. The objective of capital management is to manage each item of current assets and current debt in such a way that the desired amount of capital can be maintained. The relatively large capital will allow a unit of sale to increase the variety of its commodities. In this way, it means that it will be increasingly possible to achieve greater revenue in one period. 


\section{Definition of Profit-taking percentage}

Profit-taking percentage is the percentage of every profit taken from each item that will be sold to customers. Taking the percentage of profit is done to increase the amount of income, increase the volume of trade and invest in valuable goods. This is done to prosper the grocery stores owners. The Profit-taking percentage can be referred to as the efforts of grocery stores owners to increase the percentage of revenue by increasing the profit from each item they sell.

\section{Conceptual Framework}

As for the independent variables in this study are capital (X1), the Profit-taking percentage $(\mathrm{X} 2)$, and the dependent variable is the grocery store owner's revenue $(\mathrm{Y})$. For more details, the conceptual framework can be seen in the image below.

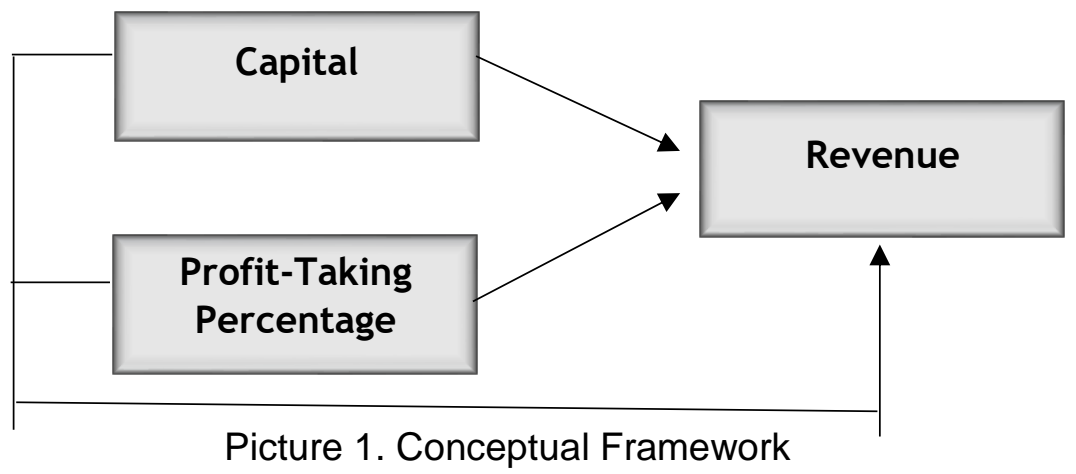

\section{Hypothesis}

Based on the framework, the hypothesis in this study, there are:

$\mathrm{H} 1$ : Capital has a positive and significant effect on the revenue of grocery store owners in Karang Anyar, Langsa

$\mathrm{H} 2$ : The profit-taking percentage has a positive and significant effect on the revenue of grocery store owners in Karang Anyar, Langsa

H3: Capital and the profit-taking percentage have a positive and significant effect on the revenue of grocery store owners in Karang Anyar, Langsa

\section{RESEARCH METHODOLOGY}

\section{Data}

The data in this study are primary data obtained through interviews with the owner of a grocery stores in Karang Anyar, Langsa. Total population is 5 grocery stores. Sampling using simple random sampling technique in this study. According to Umar (2003: 141), to determine the minimum sample size limit, the Slovin formula can be used as follows:

$\mathrm{n}=\frac{N}{1+N(e) 2}$
$\mathrm{n}=\frac{5}{1+5(0,05) 2}=4,93=5$

So the respondents in the study is 5 grocery stores in Karang Anyar, Langsa. 


\section{Operationalization of Variables}

The operational definition of this variable is carried out to set limits on the variables studied. Variable contains the following definitions:

1. Revenue is the amount of money received by the grocery store owner from the sale of products before deducting costs. Measured in rupiah units.

2. Capital is the fund or cost used to purchase merchandise from agents and distributors. Measured in rupiah units.

3. Percentage of profit is profit-taking percentage from each merchandise to be sold to customers. Measured in percent.

\section{Classic assumption test}

A model is said to be good for a predictor to have the best linear unbiased properties of an estimator. Besides that, a model is said to be quite good and can be used to predict if it has passed a series of classical assumption tests that underlie it. The classic assumption test is a normality test in this study.

\section{Data analysis method}

To answer the problems in this study, the authors perform data processing using the Eviews 11 program using the multiple linear regression method with the following equation:

$\operatorname{LnY}=a+B 1 \operatorname{LnX} 1+B 2 \operatorname{LnX} 2+B 3 \operatorname{LnX} 3+B 4 \operatorname{LnX} 4+e$

Where:

$\mathrm{Y}=$ Grocery Store Revenue

X1 = Capital

X2 = Profit-Taking Percentage

$\mathrm{a}=$ Constant

B1 - ß $4=$ Regression Parameters

$\mathrm{e}=$ Error term 


\section{DISCUSSION RESULT}

Table 2. Eviews 2020 Output Results

Dependent Variable: $Y$

Method: Least Squares

Date: 10/28/20 Time: 07:31

Sample: 15

Included observations:

5

\begin{tabular}{|l|l|l|l|l|}
\hline Variable & Coefficient & Std. Error & t-Statistic & Prob. \\
\hline X1 & 1.078 .627 & 0.032201 & 3.349 .698 & 0.0001 \\
\hline X2 & 231666.0 & 71116.69 & 3.257 .548 & 0.0472 \\
\hline
\end{tabular}

R-squared

Adjusted R-squared

S.E. of regression

Sum squared resid

Log likelihood

Durbin-Watson stat
$0.996036 \quad$ Mean dependent var

$0.994714 \quad$ S.D. dependent var

3896828. Akaike info criterion

4.56E +13 Schwarz criterion

$-8.169 .600$

Hannan-Quinn criter.

2.635.141
66600000

53598507

3.347 .840

3.332.217

3.305 .911

Source: 2020 Eviews Output Results

From the table above, it can be seen that the capital expenditure and the profit-taking percentage are positive and significant to the grocery store revenue in Karang Anyar, Langsa with a significance level of 0.05 percent. After testing the classical assumptions, normality problems were not found.

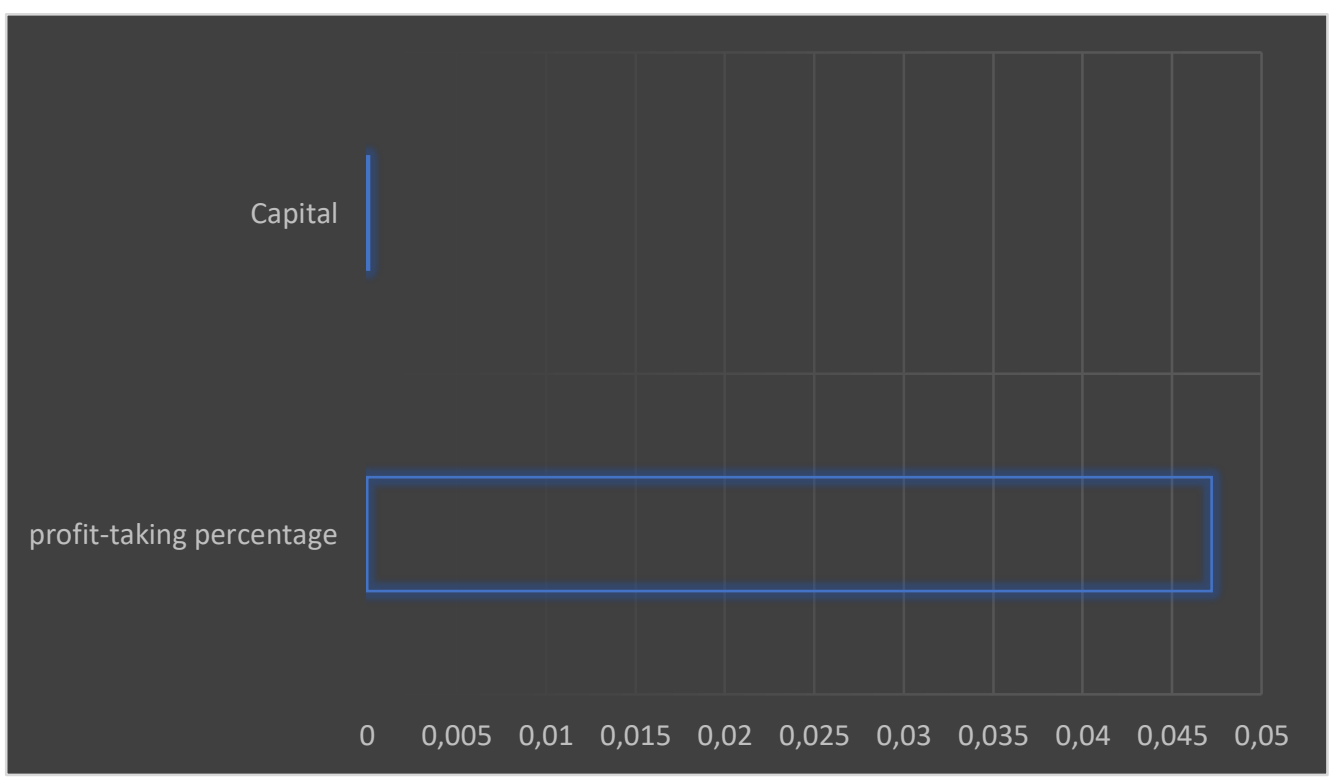

Graph 1. Variable of Capital, profit-taking percentage and revenue 
This study is based on the results of the analysis which states that the effect of capital and the profit-taking percentage has a positive impact on the grocery store revenue in Karang Anyar, Langsa. The graph above explains that if there is an increase in capital and the profittaking percentage, it will have a positive impact on the grocery store revenue in Karang Anyar, Langsa. With an increase in capital, the profit-taking percentage will also increase and revenue will also increase.

\section{CONCLUSIONS AND RECOMMENDATIONS}

\section{Conclusions}

Based on the test results from Eviews 11, it shows that capital and the profit-taking percentage simultaneously affect the revenue of grocery stores in Karang Anyar, Langsa. This means that the greater the capital used, the greater the revenue to be generated and the greater the profit-taking percentage, the greater the revenue to be generated. So the owner of a grocery stores in Karang Anyar, Langsa, must increase the capital and the profittaking percentage so that the revenue earned will also increase. However, in taking profits it is also adjusted to the needs and price standards.

\section{Recommendation}

1. The owner of a grocery stores in Karang Anyar, Langsa should increase the capital and the profit-taking percentage so that revenue increases. However, profit taking is adjusted to the needs, purchasing power of customers and the prevailing price standard.

2. grocery store owners should make financial records regarding capital, revenue, profits and losses in order to know the flow of grocery store funds.

3. Anyone who wants to research this research is expected to be able to develop this research in an innovative direction by adding variables and adding a new time span.

\section{REFERENCES}

Husaini, Ayu Fadhlani. 2017. The Influence of Working Capital, Length of Business, Working Hours and Business Location on Monza Income in Simalingkar Market Medan. Visionary \& strategic journal Volume 6, Number 2, ISSN: 2338-2864.

Nayaka, Komang Widya \& I Nengah Kartika. 2018. Effect Of Capital, Labor And Raw Materials On The Income Of Range Industry Enterprises In Pengwi District. E-Jurnal Ekonomi dan Bisnis Universitas Udayana 7.8 : 1927-1956, ISSN: 2337-3067.

Hestanto. Factors Affecting Traders' Income. Retrieved 23 November 2020 $<$ https://www.hestanto.web.id/pendapatan-pedagang/>.

Ramadhani, Niko. 2020. Functions and Understanding of Working Capital in Business. Retrieved 26 November 2020,

$<$ https://www.akseleran.co.id/blog/modal-keria/>.

Priharto, Sugi. 2020. Working Capital: Definition, Types, Examples, and Functions in Business. Retrieved 26 November 2020, 
$<$ https://accurate.id/ekonomi-keuangan/modal-kerja-pengertian-jenis-contoh-dan-

fungsinya-dalam-bisnis/>.

lqbal, Muhammad \& Talbani Farlian. 2018. The Influence Of Central Government Expenditure On The Human Development Index In Indonesia. Jurnal IImiah Mahasiswa (JIM), Vol.3 No.4 November 2018: 659-666, ISSN: 2549-8263.

Antara, Komang Adi \& Luh Putu Aswitari. 2016. Some Factors Affecting the Income of Five Foot Traders In The District Of West Denpasar. E-Jurnal EP Unud, 5[10]: 1265-1291, ISSN: 2303-0178.

Fahmi, Erwin. 2019. Effect of Labor and Production Capital on Revenue Levels at Home Industry UD Bagus Bakery Serapuh Village, Kecamatan Gunung Malela, Simalungun District. Essay. Faculty Of Islamic Economics And Business, Department of Islamic Economics, State Islamic University of North Sumatra, Medan.

Dangin, I Gede Ari Bona Tungga \& A.A.I.N. Marhaeni. 2019. Production Factors Affecting Craft's Income in the Leather Crafts Industry in Badung District. E-Jurnal Ekonomi dan Bisnis Universitas Udayana 8.7:681-710, ISSN : 2337-3067.

Yuniarti, P. 2019. Analysis of Factors Affecting Merchants' Income in Cinere Traditional Market, Depok. Widya Cipta, 3(1), 165-170.

Hanum, Nurlaila. 2017. Analysis of Factors Affecting Income Street vendors in Kuala Simpang City. JURNAL SAMUDRA EKONOMIKA, VOL. 1, NO. March 1.

Putra, Komang Gede Candra Adi \& Dr. Made Henny Urmila Dewi S.E., M.Si. 2018. Analysis of Factors Affecting Merchants' Income in Pasar Badung, Denpasar City: A Study Before And After Relocation. E-Jurnal EP Unud, 7 [6] : 1140-1167, ISSN : 2303-0178.

Nasution, Adanan Murroh. 2018. Limitations of Taking Advantage According to Islamic Law. El-Qanuny Journal Vol. 4 No, 1 January Edition.

Yatin, Sri. 2020. Grocery Store Business. Retrieved 29 November 2020, <https://noorshabirah.wordpress.com/tip-trik-usaha-kecil/usaha-toko-kelontong>.

Hestanto. 2018. Definition of Revenue. Retrieved 29 November 2020, $<$ https://www.hestanto.web.id/pengertian-pendapatan/>.

Asakdyah, Salamatun and Tina Sulistiyani. 2004. Analysis of Factors Affecting the Income Level of Traditional Market Traders in the City Yogyakarta. Journal of Management Accounting, Vol. 15, No.1, 55-64.

Economics Concepts.com. Capital as Factor of Production. Retrieved 14 December 2020, $<$ https://economicsconcepts.com/capital as a factor of production.htm>.

Amadeo, Kimberly. 2020. Factors of Production, the Four Types, and Who Owns Them. Retrieved 14 December 2020,

Firdausa, Rosetyadi Artistyan and Fitrie Arianti. 2013. Influence of Early, Old Capital Business and Working Hours of Kiosk Traders Income in Bintoro Market Demak. Diponegoro Journal Of Economics, Vol. 2 No. 1, 1-6.

$<$ https://www.thebalance.com/factors-of-production-the-4-types-and-who-owns-them4045262>

Ramadhani, Niko. 2020. Before starting a business, do you know what revenue is?, Retrieved 14 December 2020, 
<https://www.akseleran.co.id/blog/revenue-adalah/>

Suartawan , I Komang and I B Purbadharmaja. 2017. Effect Of Capital And Raw Materials On Revenue Through The Production Of Statue Crafts Wood In Kecamatan Sukawati, Gianyar District. E-Journal of Economic Development University Udayana Vol. 6 No. 9.

Dosen Pendidikan. 2020. Profit Is. Retrieved 14 December 2020, $<$ https://www.dosenpendidikan.co.id/laba-adalah/>

Atun, Nur Isni. 2016. The Effects Of Capitals, Locations, And Commodity Types On The Incomes Of The Traders At Prambanan Market, Sleman Regency. Journal of Education and Economics, Vol. 5, No. 4,

Setiaji, Khasan \& Ana Listia Fatuniah. 2018. The Influence of Capital, Length of Business and Location on Income Post Relocation Market Trader. Journal of Economics \& Business Education, 6 (1), 1-14. 